\section{Modification of Yield and Chlorophyll Content in Leaf Lettuce by HPS Radiation and Nitrogen Treatments}

\author{
Cary A. Mitchell, Tina Leakakos ${ }^{2}$, and Tameria L. Ford ${ }^{3}$ \\ Center for Plant Environmental Stress Physiology, Department of \\ Horticulture, Purdue University, West Lafayette, IN 47907
}

Additional index words. Lactuca sativa, carotenoid, high-pressure sodium, hydroponics. metal halide, quartz iodide

Abstract. This study evaluated the potential of high photosynthetic photon flux (PPF) from high-pressure sodium (HPS) lamps, alone or in combination with metal halide (MH) plus quartz iodide (QI) incandescent lamps, to support lettuce growth, with or without $\mathrm{N}$ supplementation. Varying exposures to radiation from combined HPS, MH, and QI lamps influenced dry weight gain and photosynthetic pigment content of hydroponically grown 'Black-Seeded Simpson' lettuce (Lactuca sativa L.) seedlings. Cumulative leaf dry weight declined with increasing exposure, up to 20 hours per day, to $660 \mu \mathrm{mol} \cdot \mathrm{m}^{-2} \cdot \mathrm{s}^{-1}$ of photosynthetically active radiation (PAR) from HPS lamps concomitant with constant 20 hours per day of $400 \mathrm{~m} \mathrm{~mol} \cdot \mathrm{m}^{-2} \cdot \mathrm{s}^{-1}$ from $\mathrm{MH}+\mathrm{QI}$ lamps. Leaves progressively yellowed with increasing exposure to radiation from the three-lamp combination, corresponding to lower specific chlorophyll content but not to specific carotenoid content. Lettuce grown under $\mathbf{2 0}$-hour photoperiods of 400,473 , or $668 \mu \mathrm{molm} \cdot \mathrm{m}^{-2} \cdot \mathrm{s}^{-1}$ from HPS radiation alone had the highest leaf dry weight at a PPF of $473 \mu \mathrm{mol} \cdot \mathrm{m}^{-2} \cdot \mathrm{s}^{-1}$. Chlorophyll, but not carotenoid specific content, decreased with each incremental increase in PPF from HPS lamps. Doubling the level of $\mathbf{N}$ in nutrient solution and supplying it as a combination of $\mathrm{NH}_{4}^{+}$and $\mathrm{NO}_{3}$ partially ameliorated adverse effects of high PPF on growth and pigment content relative to treatments using single-strength $\mathrm{N}$ as $\mathrm{NO}_{3}^{-}$.

Use of high-intensity discharge (HID) lamps to support plant growth in controlledenvironment chambers has the advantage of greater luminous efficacy and better lamp stability and longevity relative to use of a combination of fluorescent and incandescent lamps (Cathey and Campbell, 1980). However, clear HID lamps lack the broad-band spectral emissions characteristic of phosphor-coated fluorescent/incandescent lamp combinations. High-pressure sodium (HPS) lamps tend to be relatively "orange-biased" in their emissions (Sager, 1984), whereas standard metal halide $(\mathrm{MH})$ lamps are relatively "blue-biased" (Knight and Mitchell, 1988b). Both lamp types are relatively deficient in red and far-red waveband emissions from 650 to $750 \mathrm{~nm}$ (Tibbitts et al., 1983). Much additional research is required to characterize effects of HID lamps as sole radiation sources on a variety of crop spe-

Received for publication 28 Mar. 1990. Journal article 12431 of the Purdue Univ. Agricultural Experiment Station. Research supported in part by NASA Cooperative Agreement NCC 2-100. The authors wish to acknowledge the expert advice of J. Santini and W. Nyquist regarding experimental design and statistical analysis of data. The cost of publishing this paper was defrayed in part by the payment of page charges. Under postal regulations, this paper therefore must be hereby marked advertisement solely to indicate this fact.

'To whom correspondence should be addressed. ${ }^{2}$ Present address: Dept. of Pharmacology, College of Medicine, Univ. of California, Irvine, CA 92717. ${ }^{3}$ Present address: Agracetus Corp., 8520 University Green, Middleton, WI 53562. ties, especially at the elevated photosynthetic photon fluxes (PPFs) within the

Tibbitts et al. (1983) found 'Grand Rapids' lettuce to grow adequately using $\mathrm{MH}$ and/or HPS radiation. Although shoot dry weight was not enhanced by raising PPF from 320 to $700 \mu \mathrm{mol} \cdot \mathrm{m}^{-2} \cdot \mathrm{s}^{-1}$ from either of these HID lamp types, leaf area was reduced at the higher PPF. Chlorophyll content of this cultivar was higher at 700 than at 320 $\mu \mathrm{mol} \cdot \mathrm{m}^{-2} \cdot \mathrm{s}^{-1}$ for all lamp treatments, especially when $\mathrm{MH}$ lamps were used. In a study by Koontz et al. (1987), comparing lettuce response to $250 \mu \mathrm{mol} \cdot \mathrm{m}^{-2} \cdot \mathrm{s}^{-1}$ radiation from cool-white fluorescent lamps with that to the same PPF from HPS lamps, shoot growth was $50 \%$ greater under HPS lamps. Certain cultivars of leaf lettuce are stimulated to grow by elevated PPF from fluorescapabilities of these lamp types.

zMH, metal halide; QI, quartz iodide. from $\mathrm{MH}+$ QI lamps.

Mean \pm SEM of extracts from four plants. cent + incandescent lighting, especially if enriched $\mathrm{N}$ nutrition is available to roots as a combination of $\mathrm{NH}_{4}^{+}+\mathrm{NO}_{3}^{-}$in hydroponic culture (Knight and Mitchell, 1983a). The incandescent component of this lamp combination is particularly effective in stimulating productivity of responsive lettuce cultivars (Knight and Mitchell, 1988a).

The present study was undertaken to evaluate the potential of high PPF from HPS alone or in combination with other lamp types to support lettuce growth, especially when used with elevated $\mathrm{N}$ concentration in nutrient solutions.

Experiments were conducted in a walk-in growth chamber (Environmental Growth Chambers, Inc., Chagrin Falls, Ohio, model M11-75). The chamber was equipped with 20 water-cooled 'Sunbrella' lamp fixtures, each containing one 400-W HPS and one 400-W MH lamp in a horizontal position. Incandescent radiation was provided by twelve $300-\mathrm{W}$ water-cooled quartz iodide (QI) lamps. Energizing all three lamp types simultaneously gave a PPF of $1060 \pm 53$ $\mu \mathrm{mol} \cdot \mathrm{m}^{-2} \cdot \mathrm{s}^{-1}$ at the top of the leaf canopy (103 cm below the glass barrier of the 'Sunbrella' lamps). The HPS lamp contributed $660 \mu \mathrm{mol} \cdot \mathrm{m}^{-2} \cdot \mathrm{s}^{-1}$, while the $\mathrm{MH}$ and QI lamps provided 300 and $100 \mu \mathrm{mol} \cdot \mathrm{m}^{-2} \cdot \mathrm{s}^{-1}$, respectively. Differences in luminous efficacy accounted for the differences in PPF from these two HID lamp types. Radiation measurements were taken at the beginning and end of each 19-day experiment. A LICOR model LI-185 quantum radiometer was used to measure PPF from $400-700 \mathrm{~nm}$, and a LI-COR LI-1800 (LI-COR, Lincoln, Neb.) portable spectroradiometer was used to check the emission spectrum of each lamp type used.

The plant-growth system was constructed from vinyl guttering material (Genova) to form a series of parallel U-shaped troughs mounted on an expanded-metal table in the middle of the environmental room. Each trough was $126 \times 8 \mathrm{~cm}$ (length/width). Nutrient solution flowed through each trough at $4 \mathrm{li}$ ters $\cdot \mathrm{min}^{-1}$ and at a depth of $6 \mathrm{~mm}$. Seedlings were supported in the troughs by a PVC covering plate lined with closed-cell Ethafoam SB strips (Seward, Indianapolis, Ind.) cut to fit a series of $2.5-\mathrm{cm}$-wide slits through the plate. Four double-trough recirculating hydroponics systems were arranged side-by-side on the table in the growth room.

Table 1. Effects of HPS to supplement $\mathrm{MH}+\mathrm{QI}^{2}$ radiation and $\mathrm{N}$ source and concentration on leaf specific chlorophyll and carotenoid contents of 'Black-Seeded Simpson lettuce.

\begin{tabular}{|c|c|c|c|c|c|c|}
\hline \multicolumn{2}{|c|}{ HPS irradiation } & \multicolumn{2}{|c|}{$\begin{array}{c}\text { Nitrogen } \\
\text { concn (mM) }\end{array}$} & \multirow{2}{*}{$\begin{array}{l}\text { Chlorophyll } \\
\left(\mathrm{mg} \cdot \mathrm{g}^{-1} \mathrm{FW}\right)^{\mathbf{x}}\end{array}$} & \multirow{2}{*}{$\begin{array}{l}\text { Carotenoids } \\
\left(\mathrm{mg} \cdot \mathrm{g}^{-1} \mathrm{FW}\right)^{\mathbf{x}}\end{array}$} & \multirow{2}{*}{$\begin{array}{c}\text { Chl : Car } \\
\text { ratio }\end{array}$} \\
\hline$h \cdot$ day $^{-1}$ & $\mathrm{~mol} \cdot \mathrm{m}^{-2} \cdot \mathrm{day}^{-1}$ & $\mathrm{NH}_{4}^{+}$ & $\mathrm{NO}_{3}^{-}$ & & & \\
\hline 0 & 0 & $\begin{array}{l}5 \\
0\end{array}$ & $\begin{array}{l}25 \\
15\end{array}$ & $\begin{array}{l}433 \pm 32 \\
303 \pm 21\end{array}$ & $\begin{array}{l}72 \pm 6 \\
58 \pm 11\end{array}$ & $\begin{array}{l}6: 1 \\
5: 1\end{array}$ \\
\hline 6 & 14.3 & $\begin{array}{l}5 \\
0\end{array}$ & $\begin{array}{l}25 \\
15\end{array}$ & $\begin{array}{l}313 \pm 20 \\
286 \pm 19\end{array}$ & $\begin{array}{l}54 \pm 9 \\
55 \pm 6\end{array}$ & $\begin{array}{l}6: 1 \\
5: 1\end{array}$ \\
\hline 12 & 28.5 & $\begin{array}{l}5 \\
0\end{array}$ & $\begin{array}{l}25 \\
15\end{array}$ & $\begin{array}{l}242 \pm 18 \\
207 \pm 16\end{array}$ & $\begin{array}{l}69 \pm 3 \\
71 \pm 5\end{array}$ & $\begin{array}{l}4: 1 \\
3: 1\end{array}$ \\
\hline
\end{tabular}

yHPS at a PPF of $660 \mu \mathrm{mol} \cdot \mathrm{m}^{-2} \cdot \mathrm{s}^{-1}$ supplemented $400 \mu \mathrm{mol} \cdot \mathrm{m}^{-2} \cdot \mathrm{s}^{-1}$ for $20 \mathrm{~h} \cdot$ day-1 $\left(28.8 \mathrm{~mol} \cdot \mathrm{m}^{-2} \cdot\right.$ day $\left.{ }^{-1}\right)$ 
Table 2. Effects of HPS as a sole radiation source and $\mathrm{N}$ source and concentration on leaf specific chlorophyll and carotenoid contents of 'Black-Seeded Simpson' lettuce.

\begin{tabular}{|c|c|c|c|c|c|c|}
\hline \multicolumn{2}{|c|}{ HPS irradiation ${ }^{2}$} & \multicolumn{2}{|c|}{$\begin{array}{c}\text { Nitrogen } \\
\text { cuncn (mM) }\end{array}$} & \multirow{2}{*}{$\begin{array}{c}\text { Chlorophyll } \\
\left(\mathrm{mg} \cdot \mathrm{g}^{-1} \mathrm{FW}\right)^{\mathrm{y}}\end{array}$} & \multirow{2}{*}{$\begin{array}{c}\text { Carotenoids } \\
\left(\mathrm{mg} \cdot \mathrm{g}^{-1} \mathrm{FW}\right)^{\mathrm{y}}\end{array}$} & \multirow{2}{*}{$\begin{array}{c}\mathrm{Chl}: \mathrm{Car} \\
\text { ratio }\end{array}$} \\
\hline$\mu \mathrm{mol} \cdot \mathrm{m}^{-2} \cdot \mathrm{s}^{-1}$ & $\mathrm{~mol} \cdot \mathrm{m}^{-2} \cdot$ day $^{-1}$ & $\mathrm{NH}_{4}^{+}$ & $\mathrm{NO}_{3}^{-}$ & & & \\
\hline 400 & 28.8 & $\begin{array}{l}5 \\
0\end{array}$ & $\begin{array}{l}25 \\
15\end{array}$ & $\begin{array}{l}284 \pm 27 \\
217 \pm 12\end{array}$ & $\begin{array}{l}51 \pm 4 \\
41 \pm 3\end{array}$ & $\begin{array}{l}6: 1 \\
5: 1\end{array}$ \\
\hline 473 & 34.1 & $\begin{array}{l}5 \\
0\end{array}$ & $\begin{array}{l}25 \\
15\end{array}$ & $\begin{array}{l}248 \pm 14 \\
214 \pm 31\end{array}$ & $\begin{array}{l}47 \pm 4 \\
53 \pm 2\end{array}$ & $\begin{array}{l}5: 1 \\
4: 1\end{array}$ \\
\hline 668 & 48.1 & $\begin{array}{l}5 \\
0\end{array}$ & $\begin{array}{l}25 \\
15\end{array}$ & $\begin{array}{l}208 \pm 31 \\
128 \pm 9\end{array}$ & $\begin{array}{l}61 \pm 7 \\
50 \pm 3\end{array}$ & $\begin{array}{l}3: 1 \\
3: 1\end{array}$ \\
\hline
\end{tabular}

zHPS irradiation $20 \mathrm{~h} \cdot \mathrm{day}^{-1}$ for 12 days of treatment.

yMeans \pm SEM of extracts from four plants.

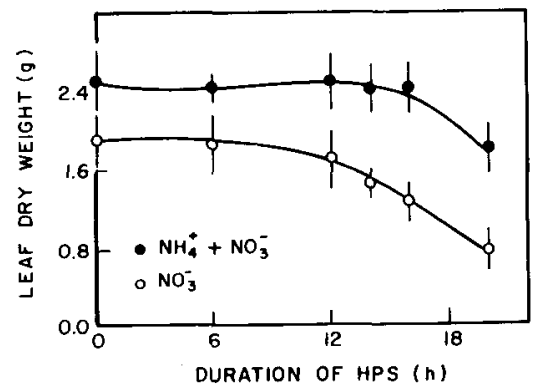

Fig. 1. Leaf dry weight per plant of 'Black-Seeded Simpson' lettuce grown for 13 days under several. durations of $660 \mu \mathrm{mol} \cdot \mathrm{m}^{-2} \cdot \mathrm{s}^{-1}$ from HPS lamps concomitant with $20 \mathrm{~h} \cdot \mathrm{day}^{-1}$ of 400 $\mu \mathrm{mol} \cdot \mathrm{m}^{-2} \cdot \mathrm{s}^{-1}$ from metal halide + quartz iodide lamps. Data points represent means of measurements from 16 plants pooled from two experiments, and vertical lines represent two SD. $\mathrm{Y}_{\mathrm{NH} 4}{ }^{+}{ }_{\mathrm{No} 3}{ }^{-}=2.5356-0.078 \mathrm{X}+0.0097 \mathrm{X}^{2}$ $-0.0004 \mathrm{X}^{3} ; R^{2}=0.41 . \mathrm{Y}_{\mathrm{NO} 3}{ }^{-}=1.8708-$ $0.0259 \mathrm{X}+0.0015 \mathrm{X}^{2}-0.00002 \mathrm{X}^{3} ; R^{2}=0.69$.

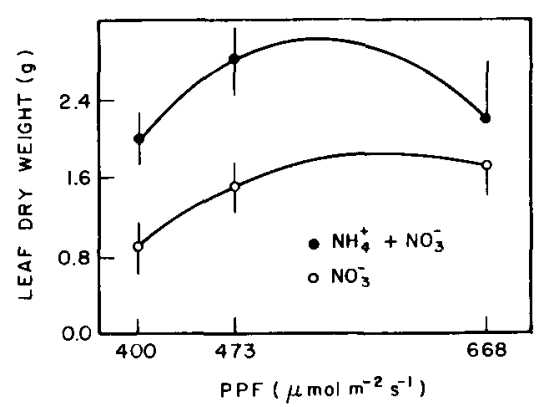

Fig. 2. Leaf dry weight per plant of 'Black-Seeded Simpson' lettuce grown for 13 days under several PPFs from HPS lamps. Data points represent means of measurements from 16 plants pooled from two experiments, and vertical lines represent two SD. $\mathrm{Y}_{\mathrm{NH} 4}{ }^{+}{ }{ }{ }^{-}{ }^{-}=1.8145+$ $1.3241 \mathrm{X}-0.5661 \mathrm{X}^{2} ; R^{2}=0.35 . \mathrm{Y}_{\mathrm{NO} 3}$ $0.8834+0.7125 \mathrm{X}-0.1599 \mathrm{X}^{2} ; R^{2}=0.62$

Seeds of 'Black-Seeded Simpson' lettuce were germinated in a furrow formed by linen cloth lining the slits of the troughs in one hydroponic system. The germination system was scaled-up, linear version of the wick method described by Knudson and Tibbitts (1973). Cloth wicks dipping into half-strength nutrient solution (Hoagland and Arnon, 1950) flowing through the troughs moistened the $\mathrm{V}$-shaped cloth furrow that supported the seeds. The Hoagland's no. 1 nutrient solution (Hoagland and Arnon, 1950) was mod- ified by providing chelated iron as Sequestrene $330 \mathrm{Fe}$. A slitted lid permitting PPF $<10$

$\mathrm{mol} \cdot \mathrm{m}^{-2} \cdot \mathrm{s}^{-1}$ at seed level covered the nurse trough for the first 2 days after sowing. After being uncovered, seedlings were grown for an additional 3 days under 20 -h photoperiods from the $\mathrm{MH}+\mathrm{QI}$ lamps. On day 5, selected seedlings were transplanted to other troughs and supported by slitted Ethafoam plugs lined with a polyester wick long enough to dip into the nutrient solution flowing 4.5 $\mathrm{cm}$ below the support plate. Six plants were spaced $18 \mathrm{~cm}$ apart in the support lid of each culture trough. Transplanted seedlings were supplied with single-strength nutrient solution, $\mathrm{pH}$ 6.0, containing $2.5 \mathrm{mM} 2-\mathrm{N}$ (Morpholino)ethanesulfonic acid (MES) buffer (Bugbee and Salisbury, 1985).

Ambient air was maintained at $25 \pm 0.5 \mathrm{C}$ throughout the experiment and measured independently with a wire-wound 1000 -Ohm sensor and a YSI thermistor/telethermometer $70 \%+5 \%$ days $/ 84 \% \pm 5 \%$ nights by two atomizing humidifiers. Humidity was measured with a shielded, aspirated $\mathrm{LiCl}$ sensor. A wet-and-dry bulb motorized psychrometer (Bendix model 566; Bendix, Baltimore, Md.) was used to verify relative humidity levels. Leaf tissue temperature was checked with an Everest model 110 infrared thermometer (Everest Interscience, Fullerton, Calif.) and was not more than $2 \mathrm{C}$ above ambient at the highest PPF used in these studies (1060 $\left.\mu \mathrm{mol} \cdot \mathrm{m}^{-2} \cdot \mathrm{s}^{-1}\right)$.

In one set of experiments, elevated PPF treatments (energizing all three lamp types simultaneously) were initiated 6 days after seeding. HPS radiation supplemented that from $\mathrm{MH}+$ QI lamps for 6, 12, 14, 16, or $20 \mathrm{~h} \cdot$ day $^{-1}$ in the middle of the $20-\mathrm{h} \mathrm{MH} \mathrm{+}$ QI regime for 13 days of treatment. Daily PPFs for these HPS treatments were 14.3, $28.5,33.3,38.0$, and $47.5 \mathrm{~mol} \cdot \mathrm{m}^{-2}$.day- ${ }^{\prime}$, superimposed over $28.8 \mathrm{~mol} \cdot \mathrm{m}^{-2} \cdot \mathrm{day}^{-1} \mathrm{MH}$ + QI radiation. In another set of experiments, lettuce growth was evaluated as a function of three PPFs with HPS lamps as the sole source of PAR during the 13-day treatment. Photon flux levels less than the maximum possible were obtained by placing a varying number of layers of cheesecloth between the lamp barriers and leaf canopy.

Nitrogen application consisted either of 15 $\mathrm{mM} \mathrm{NO}_{3}^{-}$or $5 \mathrm{~mm} \mathrm{NH}_{4}^{+}+25 \mathrm{mMNO}_{3}^{-}$in the nutrient solution (Knight and Mitchell, 1983b). The hydroponics systems were ransystem. Relative humidity was controlled at domly assigned one of the $\mathrm{N}$ treatments that were initiated on day 8 after seeding. Solution $\mathrm{pH}$ was checked daily and adjusted to maintain pH $6.0 \pm 0.3$ with $1 \mathrm{~N} \mathrm{KOH}$ or 1 $\mathrm{N}_{2} \mathrm{SO}_{4}$. On days 11 and 15 , solutions were renewed and the MES buffer concentration increased to $5 \mathrm{mM}$ for the duration of the study.

On day 18 , leaf samples were taken from four plants selected randomly from each PPF $\times \mathrm{N}$ treatment (two per trough) and analyzed for specific chlorophyll and carotenoid contents. Chlorophyll $\mathrm{a}+\mathrm{b}$ was analyzed as described by Arnon (1949). Carotenoids were determined using methods outlined by Liaanen-Jensen and Jensen (1971). Pigments were determined in leaf extracts using a Beckman DU-50 spectrophotometer (Beckman Instruments, Irvine, Calif.).

A split-plot design was used in which two of the four hydroponics systems within the growth chamber were randomly selected for each of the two $\mathrm{N}$ treatment groups within each radiation regime. The design included radiation regime as a treatment over time within a single growth room. The eight plants remaining in a treatment group after harvest for pigment analysis on day 18 were harvested on day 19 for growth analysis. Measured growth characteristics included stem length, leaf count and area, and fresh weight of leaves, stems, and roots. Harvested plant material was dried for 3 days at $75 \mathrm{C}$ in a forced-air oven. Samples were equilibrated to room temperature and humidity before dry weights were determined. Each growth experiment was repeated and data from replicated experiments were pooled for nonlinear regression analysis of leaf dry weight per plant as a function of radiation and $\mathrm{N}$ treatment.

Cumulative leaf dry weight of 'BlackSeeded Simpson', a very light green, looseleaf cultivar, was measured after exposure to varying durations of high-PPF irradiation from HPS lamps (6 to $20 \mathrm{~h} \cdot$ day $^{-1}$ ) while $\mathrm{MH}+$ QI lamps were energized for the same $20 \mathrm{~h}$ during each 24-h cycle. Lettuce leaves developed no morphological abnormalities and little marginal tipburn in response to radiation or $\mathrm{N}$ treatments tested in this study. However, treatment effects on leaf size, mass, and color were evident. At no duration of exposure to high PPF from HPS + MH + QI lamps was leaf dry weight enhanced reltive to that when only $\mathrm{MH}+$ QI lamps were energized (Fig. 1). Without an HPS component of the radiation spectrum, $\mathrm{N}$ supplementation enhanced leaf dry-weight gain $32 \%$ relative to $15 \mathrm{mM} \mathrm{NO}_{3}^{-}$controls. Inhibition of cumulative leaf dry weight gain by HPS irradiation became evident at $12 \mathrm{~h} \cdot \mathrm{day}^{-1} \mathrm{ex}$ posure or longer when $15 \mathrm{mmNO}_{3}$ was used. Exposure to HPS radiation for $20 \mathrm{~h} \cdot$ day-1 inhibited productivity $58 \%$ relative to no HPS radiation. However, $\mathrm{N}$ supplementation increased tolerance to HPS exposure for up to $16 \mathrm{~h} \cdot \mathrm{day}^{-1}$. At $20 \mathrm{~h} \cdot$ day $^{-1} \mathrm{HPS}$, leaf dry weight gain was inhibited $24 \%$ relative to no HPS when $\mathrm{N}$ was supplemented.

Increasing duration of daily exposure to HPS radiation concomitant with $20 \mathrm{~h} \cdot \mathrm{day}^{-1}$ 
$\mathrm{MH}+\mathrm{QI}$ radiation caused increasing increments of visible yellowing of 'Black-Seeded Simpson' lettuce leaves. The degree of yellowing appeared similar for 12-, 14-, 16-, and 20-h exposures to HPS radiation relative to $\mathrm{MH}+\mathrm{QI}$ (0 HPS) controls. HPS radiation for $12 \mathrm{~h} \cdot \mathrm{day}^{-1}$ also reduced leaf specific chlorophyll content (Table 1). However, N supplementation enhanced visible leaf greenness and partially negated the chlorophyll reduction caused by $12 \mathrm{~h} \cdot \mathrm{day}^{-1} \mathrm{HPS}$ radiation. The fact that $\mathrm{N}$ supplementation also enhanced specific chlorophyll content of $\mathrm{MH}+\mathrm{QI}$ controls indicates that $\mathrm{N}$ nutrition became limiting to specific chlorophyll content under the unsupplemented $\mathrm{N}$ nutrition protocol used. The data also indicate a definite and separate deleterious effect of 12 $\mathrm{h} \cdot$ day $^{-1}$ supplemental HPS radiation per se on specific chlorophyll content. Although Nsupplemented plants receiving $12 \mathrm{~h} \cdot \mathrm{day}^{-1}$ HPS radiation contained $44 \%$ less chlorophyll than $\mathrm{N}$-supplemented plants receiving no HPS radiation, leaf dry weight per plant was not affected (Fig. 1), indicating that sufficient chlorophyll remained to support normal photosynthetic productivity, even after receiving a chlorophyll-reducing dosage of HPS radiation.

In contrast to effects on chlorophyll, there were no consistent effects of HPS exposure for 6 or $12 \mathrm{~h} \cdot$ day $^{-1}$ on leaf specific carotenoid content. Nitrogen supplementation also had no large effect on carotenoids. However, $\mathrm{N}$ supplementation consistently raised the chlorophyll : carotenoid ratio for all radiation treatments, whereas $12 \mathrm{~h} \cdot$ day $^{-1} \mathrm{HPS}$ lowered it. Without HPS radiation, the chlorophyll : carotenoid ratio was $6: 1$, whereas $12 \mathrm{~h} \cdot \mathrm{day}^{-1} \mathrm{HPS}$ decreased it to 3:1. Thus, the yellower appearance of 'Black-Seeded Simpson' leaves exposed to increasing dosages of HPS radiation was due to reduced specific chlorophyll content rather than to increased specific carotenoid content. The lowered chlorophyll : carotenoid ratio likely contributed to the yellow appearance of leaves exposed to supplemental HPS radiation.

Previous studies with leaf lettuce grown at high PPF form fluorescent plus incandescent lamps indicated a positive growth response to a doubling of initial $\mathrm{N}$ concentration in the nutrient solution (Knight and Mitchell, 1983a).In those studies, $\mathrm{NO}_{3}$ was depleted $50 \%$ before refreshing solutions of $30 \mathrm{mM}$ $\mathrm{NO}_{3}$ was used, as opposed to $>80 \%$ when $15 \mathrm{mmNO}_{3}$ was used. Growth was stimulated at high PPF in response to doubling $\mathrm{NO}$; alone, but the greatest growth response was to $\mathrm{NH}_{4}^{+}+\mathrm{NO}_{3}^{-} \cdot \mathrm{NH}_{4}^{+}$disappearance from this solution was $>90 \%$ before the plants began taking up $\mathrm{NO}_{3}$ in significant amounts. In the present study, using a similar $\mathrm{N}$ supplementation protocol, but HID lamp types, leaf lettuce. did not grow nearly as rapidly and probably depleted $\mathrm{N}$ much less, although $\mathrm{NO}_{3}$ and $\mathrm{NH}_{4}^{+}$in solution were not measured. Double-strength $\mathrm{N}$, as $5 \mathrm{mM} \mathrm{NH}_{4}^{+}+$ $25 \mathrm{mM} \mathrm{NO}_{3}$, partially ameliorated the deleterious effects of supplemental HPS radiation on growth and specific chlorophyll content of 'Black-Seeded Simpson' leaf let- tuce, but not sufficient to stimulate yield relative to no HPS lighting.

To determine whether reduced leaf dry weight gain and loss of chlorophyll were caused specifically by the HPS component of the high-PPF radiation treatments, followup experiments were conducted in which HPS was the sole source of radiation from days 6 to 19 after seeding. Without $\mathrm{N}$ supplementation, leaf dry weight was no higher at 668 $\mu \mathrm{mol} \cdot \mathrm{m}^{-2} \cdot \mathrm{s}^{-1}$ of HPS radiation (no shadecloth) than at $473 \mu \mathrm{mol} \cdot \mathrm{m}^{-2} \cdot \mathrm{s}^{-1}$ ( one layer), but $400 \mu \mathrm{mol} \cdot \mathrm{m}^{-2} \cdot \mathrm{s}^{-1}$ (two layers) tended to limit leaf dry weight gain (Fig. 2). Nitrogen supplementation not only enhanced lettuce productivity at all PPFs tested, but also better defined the upper tolerance limit of 'Black-Seeded Simpson' lettuce to radiation flux from HPS lamps. Leaf dry weight of $\mathrm{N}$ supplemented plants was higher with 473 $\mu \mathrm{mol} \cdot \mathrm{m}^{-2} \cdot \mathrm{s}^{-1}$ of PAR than with 400 or 668 $\mu \mathrm{mol} \cdot \mathrm{m}^{-2} \cdot \mathrm{s}^{-1}$ after 13 days of exposure to HPS radiation for $20 \mathrm{~h} \cdot \mathrm{day}^{-1}$. Yield response to PPF with $\mathrm{N}$ supplementation indicates a fairly narrow range of tolerance before increasing HPS radiation becomes limiting to 'Black-Seeded Simpson' leaf lettuce. This finding is in sharp contrast to previous reports that elevation of PPF enhances productivity of leaf lettuce (Knight and Mitchell, 1983a, 1988a). However, the radiation sources used in those studies were a combination of incandescent + fluorescent lamps, with as much as $84 \%$ of total irradiance supplied by incandescent lamps. Certain cultivars of lettuce respond favorably to high-PPF fluorescent + incandescent radiation (Knight and Mitchell, 1983a), especially when used in combination with enriched $\mathrm{N}$ supplied as $\mathrm{NH}_{4}^{+}+\mathrm{NO}_{3}$. The present study indicated that a very light green cultivar of leaf lettuce is rather intolerant of PPFs $>600 \mu \mathrm{mol} \cdot \mathrm{m}^{-2} \cdot \mathrm{s}^{-1}$ if the radiation is supplied by HPS lamps. The extent to which this negative response is common to other lettuce cultivars will require additional research. Previous studies using HPS lamps at a (low) PPF of $250 \mu \mathrm{mol} \cdot \mathrm{m}^{-2} \cdot \mathrm{s}^{-1}$ have given acceptable lettuce yield (Koontz et al., 1987), further indicating the advantage of using low or intermediate rather than high PPF from HPS lamps for lettuce culture.

Specific chlorophyll content of leaves decreased with increasing PPF from HPS lamps, with or without $\mathrm{N}$ supplementation (Table 2). Once again, chlorophyll decreased even as growth increased (cf. Table 2, Fig. 2), reinforcing the notion that chlorophyll content per se was not the factor most limiting photosynthetic productivity within the range of PPF values tested. Carotenoid content did not vary much with PPF. The chlorophyll : carotenoid ratio once again decreased with increasing PPF, concomitant with visual yellowing of the tissues at $668 \mu \mathrm{mol} \cdot \mathrm{m}^{-2} \cdot \mathrm{s}^{-1}$. Tibbitts et al. (1983) also found reduced chlorophyll content of lettuce grown under HPS lamps without a difference in yield.

If HPS radiation is deficient in one or more wavebands important for leaf development and specific chlorophyll content of light green leaf lettuce, then increasing the level and/or duration of exposure to HPS radiation might be expected to stimulate these components as the level of the deficient factor is raised. Since there were no stimulations but rather ranges of "tolerance" followed by strong trends toward inhibition, our results suggest that the high levels and/or high dosages of HPS radiation have a deleterious effect on leaf lettuce. We suspect that the basis of the growth and chlorophyll reductions caused by high-PPF HPS in the present study involves lamp emissions beyond the spectral ranges measured by PAR meters and standard spectroradiometers.

The possible use of higher plant food crops in future, space-deployed bioregenerative life support systems (Hoff et al., 1982, Tibbitts and Alford, 1980), requires that energetically efficient radiation sources be investigated to assess their cost : benefit ratio for growth of candidate crop species under controlled-environment conditions. The results of this study suggest that high PPF from HPS lamps cannot be used to obtain the high productivity rates with leaf lettuce that have been demonstrated with lamp types of lower luminous efficacy and less output stability. Development of efficient, effective radiation sources with an emission spectrum appropriate for optimum productivity of leaf lettuce is eagerly awaited.

\section{Literature Cited}

Arnon, D.I. 1949. Copper enzymes in isolated chloroplasts. Polyphenoloxidase in Beta vulgaris. Plant Physiol. 24:1-15.

Bugbee, B.G. and F.B. Salisburv. 1985. An evaluation of MES (2(N-Morpholino)ethanesuIfonic acid) and amberlite IRC-5O as $\mathrm{pH}$ buffers for nutrient solution studies. J. Plant Nutr. 8(7):567583.

Cathey, H.M. and L.E. Campbell. 1980. Light 'and lighting systems for horticultural plants,p. 491-537. In: J. Janick (ed.). Horticultural reviews. vol. 2. AVI, Westport, Conn.

Hoagland, D.R. and D.I. Arnon. 1950. The water culture method for growing plants without soil Calif. Expt. Sta. Circ. 347 (rev.).

Hoff, J.E., J.M. Howe, and C.A. Mitchell. 1982. Nutritional and cultural aspects of plant species selection for a regenerative life support system. NASA Contractor Rpt. 166324, Washington, D.C.

Knight, S.L. and C.A. Mitchell. 1983a. Enhancement of lettuce yield by manipulation of light and nitrogen nutrition. J. Amer. Soc. Hort. Sci. 108:750-754

Knight, S.L. and C.A. Mitchell. 1983b. Stimulation of lettuce productivity by manipulation of diurnal temperature and light. HortScience 18(4):462-463.

Knight, S.L. and C.A. Mitchell. 1988a. Effects of incandescent radiation on photosynthesis, growth rate and yield of 'Waldmann's Green' leaf lettuce. Scientia Horn. 35:37-49.

Knight, S.L. and C.A. Mitchell. 1988b. Growth and yield characteristics of 'Waldmann's Green' leaf lettuce under different photon fluxes from metal halide or incandescent + fluorescent radiation. Scientia Hort. 35:51-61.

Knudson, L.L. and T.W. Tibbitts. 1973. Wickaction method for germination of seeds. HortScience 8:472.

Koontz, H.V., R.P. Prince, and R.F. Koontz. 1987. 
Comparison of fluorescent and high-pressure sodium lamps on growth of leaf lettuce. HortScience 22:424-425.

Liaanen-Jensen, S. and A. Jensen. 1971. Quantitative determination of carotenoids in photosynthetic tissues, p. 586-602. In: A. San Pietro, (ed.). Methods in enzymology, vol. 23. Pho- tosynthesis, part A. Academic, New York.

Sager, J.C. 1984. Spectral effects on the growth of lettuce under controlled environment conditions. Acta Hort. 148:889-896.

Tibbitts, T.W. and D.K. Alford. 1980. Use of higher plants in regenerative life support systerns. NASA Conf. Pub. 2231, Washington,
D.C.

Tibbitts, T.W., D.C. Morgan, and I.J. Warrington. 1983. Growth of lettuce, spinach, mustard, and wheat plants under four combinations of high-pressure sodium, metal halide, and tungsten halogen lamps at equal PPFD. J. Amer. Soc. Hort. Sci. 108:622-630. 